\title{
The Juridical Criminal Construction of Corruption Extortion in Taxation Sector Related to State Financial Losses
}

\section{Lilik Perdana*) and Sri Endah Wahyuningsih ${ }^{* *}$ )}

*) Faculty of Law, Universitas Islam Sultan Agung (UNISSULA) Semarang, E-mail: lilikperdana80@gmail.com

**) Faculty of Law, Universitas Islam Sultan Agung (UNISSULA) Semarang

\begin{abstract}
.
The purpose of this article is to analyze the juridical construction of the criminal act of extortion corruption in the taxation sector. The method used is normative juridical, both in the narrow sense and in the broad sense. While the analysis orientation is in the form of a conceptual approach (Concept Approach) and a statutory approach (Statue Approach). The results of the research obtained are the primary indictment model, Article 12 letter $e$ of the Anti-Corruption Law in conjunction with Article 55 paragraph (1) of the 1st Criminal Code. Subsidiary, Article 23 of the Anti-Corruption Law in conjunction with Article 421 in conjunction with Article 55 paragraph (1) of the 1st Criminal Code as a fulfillment of its legality principle. Meanwhile, the principle of culpability is in the form of the defendant's intentional coercion of the taxpayer through his role as a person to participate in committing a crime (medepleger).
\end{abstract}

Keywords: Corruption; Crime; Culpability; Legality; Principle.

\section{Introduction}

Criminal law as a means of protecting society, experiences challenges when there is more than one statutory regulation governing criminal acts committed by perpetrators of criminal acts. It can be concretized that the confusion in law enforcement includes the overlapping authority of law enforcement officers, be it the Police, Prosecutors and Civil Servant Investigators (PPNS). For example, the criminal act of extortion by unscrupulous tax officers against taxpayers (Case Case No. 18/Pid.Sus-TPK/2021/PN SMG). This legal fact shows that there is a potential for conflict of special criminal law rules with other special crimes. In a quo case, between corruption and tax crimes.

The principle of systematic lex specialis in legal principles is present as a solution to the problems of special criminal law that are outside the parent system (KUHP). In addition, this principle also acts as a way out if there is a conflict between one law and another where the law is a special criminal law. ${ }^{1}$ In the context of this article, the author takes a special criminal law perspective in the field of taxation and criminal law specifically for corruption. So that by systematically studying the juridical construction in a quo case, it is possible to see the legal arguments for the application of the systematic Lex specialis principle.

Legal facts that describe that the tax criminal law is theoretically called ius singular, but in reality the actions of the tax authorities or tax officers that harm state

\footnotetext{
${ }^{1}$ Edward Omar Sharif Hiariej, 2021, "Asas Lex Specialis Systematis dan Hukum Pidana Pajak”, Jurnal Penelitian Hukum De Jure Volume 21 Nomor 1, March 2021, p.1 https://ejournal.balitbangham.go.id/index.php/dejure/article/view/1623
} 
finances are tried under the corruption law, for example the case of Gayus Tambunan who received a cassation decision in 2012 was prosecuted by the prosecutor using The Anti-Corruption Law is not with the provisions of the tax criminal law ${ }^{2}$. This reality is a legal insight on how the enforcement of special criminal law which has provisions for elements of state financial or economic losses is regulated by more than one special criminal law.

The element of state financial or economic loss is one of the elements of a criminal offense which is regulated by more than one special criminal law provision. The crime of corruption specifically places this element as a formal requirement that must be proven in the law enforcement process. Buscaglia and van Dijk define corruption as the abuse of public authority for private gain ${ }^{3}$. This type of crime can take the form of bribery, grand corruption, petty corruption, extortion, embezzlement, fraud, and trading in influence. ${ }^{4}$. Case No. 18/Pid.Sus-TPK/2021/PN SMG is a legal fact that describes the position of the case as follows: ${ }^{5}$ The program to eliminate tax arrears has become a correlative factor for criminal acts. Actors qualified as Civil Servants or State Organizers, commit a series of actions that benefit themselves or others against, or by abusing their power to force someone to give something, pay or receive payment with a discount or to do something for himself. The mode used is to extort taxpayers by asking for IDR 120,000,000.00 (one hundred and twenty million rupiah) and if the money submitted is less than IDR $120,000,000.00$ (one hundred and twenty million rupiah) will be e-billing and will be billed again for the total amount of arrears of IDR376,850,942, 00 (three hundred and seventy-six million eight hundred fifty thousand nine hundred and forty-two rupiah). On August 4, 2020 at around 17.00 WIB at the Coffee Starbuck Court Jl. Gajah Mada No. 111 Semarang, the victim handed over IDR 38,550.000,00 (thirty eight million five hundred fifty thousand rupiah) received by the suspect. Simultaneously with the incident, Investigators from Sub-Directorate 3 of the Ditreskrimsus Polda Central Java conducted arrests.

Research related to the theme of the article can be compiled as follows: research finds legal system problems related to legal substance in law enforcement regarding corruption that is detrimental to state finances and problems in the legal system related to the legal structure in law enforcement in Indonesia on criminal acts of corruption that harm state finances ${ }^{6}$. In addition, it was found that the implementation of law enforcement in cases of conspiracy related to corruption is currently unfair, this is due to the unclear elements in the criminal act of conspiracy in corruption cases so that existing law enforcement is based on political interests, where the authorities will be able to seek a way out of the snare Article 15 of Act No. 31 of 1999 Jo. Act No. 20 of 2001 concerning Eradication of Criminal Acts of

\footnotetext{
2 Ibid, p.1

${ }^{3}$ Edgardo Buscaglia dan Jan van Dijk, 2003, Controlling organized crime and corruption in the public sector, Forum on Crime and Society, 3 (1-2), p. 3-34

4 United Nations Office on Drugs and Crime (UNODC) (5), UN Guide for Anti-Corruption Policies, https://www.unodc.org/pdf/crime/corruption/UN Guide.pdf

5 Minutes of Opinion, Investigation Order Number: Sprin.Sidik/771/VII/2020/Reskrimsus dated August 5, 2020

${ }^{6}$ M. Rizal Bagaskoro and Jawade Hafidz, "Evidence System of Counting Elements of State Loss Against Corruption Criminal Actions in Indonesian Criminal Jurisdiction System”, Law Development Journal, Vol 2, No 4, 2020 http://jurnal.unissula.ac.id/index.php/ldj/article/view/14775
} 
Corruption, while parties who do not have the authority to power will not be able to escape from the snares of Article 15 of Act No. 31 of 1999 Jo. Act No. 20 of 2001 concerning Eradication of Criminal Acts of Corruption 7 . Meanwhile, in the realm of prosecuting corruption crimes, it was found that the role of the Public Prosecutor in Prosecuting Defendants of Corruption Crimes, namely the public prosecutor in prosecuting corruption crimes, was sufficient to prove the fulfillment of the elements of corruption. Corruption violated by the defendant as a result of the actions committed. Starting from the investigation, prosecution, legal action which then if it has permanent legal force, the prosecutor's office in carrying out the prosecution of criminal acts of corruption is regulated in Article 137, Article 139 and Article 143 of the Criminal Procedure Code and Act No. 16 of 2004 concerning the Attorney General's Office of the Republic of Indonesia. Indonesia, thereby giving confidence to the judge that the defendant's actions had violated the criminal provisions he was charged with. Examination of the Cassation Level for Legal Interests (Article 259 of the Criminal Procedure Code). Review of Court Decisions That Have Permanent Legal Force (Article 263 of the Criminal Procedure Code) ${ }^{8}$. In relation to state financial losses, the study found that efforts to recover assets resulting from criminal acts of corruption through additional criminal payments of replacement money based on the provisions of Article 18 paragraph (1) letter b of Act No. 31 of 1999 jo. Act No. 20 of 2001. The purpose of imposing additional sanctions is to ensure that state financial losses caused by actions can be recovered to the state through the imposition of additional fines for payment of compensation. The judge in deciding the amount of additional punishment for paying compensation to the defendant based on legal facts at trial that prove the amount of property obtained by the defendant from the crime of corruption ${ }^{9}$.

Based on the background of these problems, the authors examine in more depth about the juridical construction of criminal acts of corruption, extortion qualifications related to tax officials.

The purpose of this article is to analyze the juridical construction of criminal acts of corruption qualifying extortion by tax officials based on Act No. 31 of 1999 in conjunction with Act No. 20 of 2001 concerning Corruption Crimes.

\section{Research Methods}

The approach method used in this research is normative juridical. The research data uses secondary data consisting of primary legal materials, secondary legal materials and tertiary legal materials. Meanwhile, the analysis orientation uses a conceptual approach (Concept Approach) and a statutory approach (Statue Approach).

\footnotetext{
7 Haryono , Bambang Tri Bawono, Relevance of Legal Certainty In Criminal of Consent In The Eradication of Corruption Law, Law Development Journal, Vol 3, No 3, 2021 http://jurnal.unissula.ac.id/index.php/ldj/issue/view/562

${ }^{8}$ Agung Nugroho Santoso, Sri Kusriyah, Role Of Public Prosecutors In Corruption Crime Prosecution, Law Development Journal, Vol 3, No 2, 2021

${ }^{9}$ Hery Purwanto, Siti Ummu Adillah ,The Recovery Of Assets Results Of Corruption Through Additional Criminal Payment Of Replacement Money, Law Development Journal, Vol 3, No 2 , 2021
} 


\section{Results and Discussion}

Act No. 31 of 1999 in conjunction with Act No. 20 of 2001 concerning Criminal Acts of Corruption (Corruption Law) is based on (1) "Nullum delictum nulla poena sine praevia legi poenali", which can be interpreted as: "No offense, no a criminal offense without a criminal provision that precedes it. (2) The principle of presumption of guilt, namely if the defendant cannot prove the origin of his assets, the defendant can be blamed for the crime of money laundering. (3) the principle of Lex Specialis and (4) the principle of absence.

The purpose of the Anti-Corruption Law is formulated as to create a just, prosperous and prosperous Indonesian society, it is necessary to continuously improve the prevention and eradication of criminal acts in general and corruption in particular. In essence, this goal is divided into two, namely general goals and specific goals. The means of criminal law have been recognized by lawmakers from the start as an effort to mandate the constitution, namely to create a just, prosperous and prosperous society (general goal). The specific objective in the formulation of the Anti-Corruption Law is an effort to prevent and eradicate corruption which is realized to be detrimental to the state's finances and or economy.

Some new guidelines ${ }^{10}$ related to the specificity of the Anti-Corruption Law, in terms of enforcing the law on corruption which is difficult to prove, a joint team is coordinated by the Attorney General, while the investigation and prosecution process is carried out in accordance with the applicable laws and regulations. The purpose of this rule or guideline is to improve time efficiency in handling corruption crimes and at the same time protect the human rights of suspects or defendants. In addition, the Anti-Corruption Law also regulates how to expedite the process of investigating, prosecuting and examining criminal acts of corruption, through setting the authority of investigators, public prosecutors, or a judge according to the level of case handling to be able to directly request information about the financial condition of the suspect or defendant to the bank by submitting the matter to the Governor of Bank Indonesia. Another special rule, in the form of applying reverse evidence that is limited or balanced, is that the defendant has the right to prove that he has not committed a criminal act of corruption and is obliged to provide information about all of his property and the property of his wife or husband, children, and the property of any person or corporation that is suspected of having a relationship with the case in question, and the public prosecutor is still obliged to prove his indictment. Public participation in preventing and eradicating corruption is wide open with the enactment of this Anti-Corruption Law.

A systematic study of the Anti-Corruption Law and cases of criminal acts of corruption in the taxation sector, the elements of Criminal Corruption in the Qualification of Extortion Corruption Case No. 18/Pid.Sus-TPK/2021/PN SMG can be described as follows:

a. Elements of "A civil servant"

Judge's consideration: Does the Defendant have the qualities of "a civil servant"?

b. The element of "abusing power"

${ }^{10}$ General explanation of Act No. 31 of 1999 
The panel of judges is of the opinion that what must be considered in the element of "abuse of power" is whether the Defendant has committed the acts as charged by the Public Prosecutor in his indictment and whether the Defendant's actions abused his power?

c. The element of "forcing someone to do, not do, or allow something"

Based on the consideration of the panel of judges, to prove this element, the act that was tested at trial was whether the defendant's actions were acts of forcing someone by abusing their power to do, not do, or allow something.

d. The element "those who do, who orders to do, or who participate in doing" In the law of evidence, what is done by the panel of judges to examine participation in a crime as regulated in Article 55 paragraph (1) of the 1st Criminal Code in the indictment of the Public Prosecutor is to find out what role the Defendant has played in the event of participation in a crime or crime committed by 2 (two) or more persons?

The juridical construction of Corruption Extortion by Tax Officers in proving the panel of judges regarding the elements in a quo case can be explained as follows:

Ad. a) Article 1 point 2 of Act No. 31 of 1999 concerning the Eradication of Criminal Acts of Corruption, as amended by Act No. 20 of 2001 concerning Amendments to Act No. 31 of 1999 concerning Eradication of Criminal Acts of Corruption, based on the provisions of Article 1 number 2 of Act No. 5 of 2014 concerning State Civil Apparatus, based on Article 92 of the Criminal Code, and based on the provisions of Article 1 number 3 of Act No. 5 of 2014 concerning State Civil Apparatus.

Ad. b) Based on Article 1 point 6, Article 5 paragraph (1) and Article 41 paragraph (1) Act No. 19 of 1997 concerning Collection of Taxes by Forced Letter as amended by Act No. 19 of 2000 concerning Amendments to Act No. 19 of 1997 concerning Collection of Taxes by Forced Letter which basically regulates "Tax collection is not carried out if it has expired as regulated in regional laws and regulations".

Ad. c) Through the following stages: first, the panel of judges argued that the juridical definition of coercion is psychological. Second, the panel of judges tested at trial the phrase "or" which is alternative in the juridical formulation: "forcing someone to do, not to do, or to allow something" which is proven to be doing something. So that the argument of the panel of judges can be formulated that the Defendant's actions are more psychological in nature by abusing their power to "do something", namely forcing the witness to give a sum of money to the Defendant.

Ad. d) The panel of judges seems to believe that the actions of the Defendant are clear in a series of cooperation in such a way that they are closely related to one another in order for the intended action to take place. It is proven that there are 2 (two) or more people who committed and those who participated in the criminal incident, namely the Defendant and witness $\mathrm{R}$ Bin $\mathrm{S}$, so that the position of the Defendant in this case is as a person who participated in committing a crime (medepleger).

With the information above, in essence criminal act of corruption, extortion in the taxation sector is a criminal event that contains the principle of legality (fulfillment of the juridical formulation of a written crime in laws and regulations) and the principle of culpability (no crime without error). The legality principle is 
juridically constructed in Article 1 number 2 of the Anti-Corruption Law, Article 92 of the Criminal Code and Article 1 number 3 of Act No. 5 of 2014 concerning State Civil Apparatus. The systematic construction of these articles is a means of fulfilling the quality elements of the accused as civil servants or state administrators. The element of abusing power is proven by the juridical basis in Article 1 point 6, Article 5 paragraph (1) and Article 41 paragraph (1) of Act No. 19 of 1997 concerning Collection of Taxes by Forced Letters as amended by Act No. 19 of 2000 concerning Amendments to Act No. 19 of 1997 concerning Collection of Taxes By Forced Letter. The element of coercion is proven through a juridical basis which is regulated in the phrase "A coercive act is an act by suppressing the will of another person that is contrary to the will of the person being suppressed itself. Forcing by abusing power is more psychological, not physical. The element of concurrent criminal acts (concursus) is based on Article 55 paragraph (1) 1 of the Criminal Code so that it is proven that the position of the Defendant in this case is as a person who participated in committing a crime (medepleger).

The principle of no crime without error (principle of culpability), as the principle of monodualism in criminal law, explains that the crime of extortion in the taxation sector in a quo case is in the form of the defendant's intentional coercion of taxpayers through the role of a person participating in criminal acts (medepleger).

Case $a$ quo of defendant was indicted by the public prosecutor through a systematic indictment: 1 . Primary Indictment, the suspect violated the provisions of Article 12 letter e of the Anti-Corruption Law, which is punishable by life imprisonment or imprisonment for a minimum of 4 (four) years and a maximum of 20 (two) years. twenty) years and a minimum fine of IDR 200,000,000.00 (two hundred million rupiah) and a maximum of IDR 1,000,000,000.00 (one billion rupiah)". Meanwhile, other criminal acts that are in accordance with the legal facts are formulated in Article 55 paragraph (1) 1st: "(1) Sentenced as perpetrators of criminal acts: 1. those who commit, who order to do, and who participate in doing the deed" as a form of participation in a criminal act. 2. Subsidiary Indictment,

The decision of the Panel of Judges in a quo case, sentenced the defendant to a certain period of imprisonment ( 1 year 6 months) and a fine of IDR 50,000,000 (fifty million rupiah), with the provision that if the fine was not paid, it was replaced with imprisonment for 2 (two) months.

\section{Clossing}

The juridical construction of the criminal act of extortion of corruption against taxpayers, as in the model of the indictment constructed by the Public Prosecutor, is subsidiarity with the juridical construction: primary, Article 12 letter e of the Anti-Corruption Law in conjunction with Article 55 paragraph (1) 1 of the Criminal Code. Subsidiary, Article 23 of the Corruption Law in conjunction with Article 421 in conjunction with Article 55 paragraph (1) of the 1st Criminal Code. The principle of legality was proven at trial by balancing the principle of culpability in the form of: The defendant intentionally forced the taxpayer through his role as a person to participate in committing a criminal act (medepleger). It is necessary to consider the pattern of effectiveness and efficiency in law enforcement using 
criminal means, so that it has an impact on criminal acts and prevents potential criminals, especially tax crimes related to corruption.

\section{References}

\section{Journals}

[1] Agung Nugroho Santoso and Sri Kusriyah, "Role Of Public Prosecutors In Corruption Crime Prosecution", Law Development Journal, Vol 3, No 2, 2021, http://jurnal.unissula.ac.id/index.php/ldj/issue/view/554

[2] Edgardo Buscaglia dan Jan van Dijk, 2003, Controlling organized crime and corruption in the public sector, Forum on Crime and Society

[3] Edward Omar Sharif Hiariej, 2021, "Asas Lex Specialis Systematis dan Hukum Pidana Pajak", Jurnal Penelitian Hukum De Jure Volume 21 Nomor 1, March 2021

https://ejournal.balitbangham.go.id/index.php/dejure/article/view/1623

[4] Haryono and Bambang Tri Bawono, "Relevance Of Legal Certainty In Criminal Of Consent In The Eradication Of Corruption Law", Law Development Journal, Vol.3,No.3,2021, http://jurnal.unissula.ac.id/index.php/ldj/issue/view/562

[5] Hery Purwanto and Siti Ummu Adillah, "The Recovery Of Assets Results Of Corruption Through Additional Criminal Payment Of Replacement Money", Law Development Journal, Vol 3, No 2, 2021, http://jurnal.unissula.ac.id/index.php/ldj/issue/view/554

[6] M. Rizal Bagaskoro and Jawade Hafidz, "Evidence System of Counting Elements of State Loss Against Corruption Criminal Actions in Indonesian Criminal Jurisdiction System", Law Development Journal, Vol 2, No 4, 2020, http://jurnal.unissula.ac.id/index.php/ldj/issue/view/518

\section{Books}

[1] Artidjo Alkostar, 2018, Metode Penelitian Hukum Profetik, FH UII Press, Yogyakarta

[2] Barda Nawawi Arief, 2012, Kebijakan Formulasi Ketentuan Pidana Dalam Peraturan Perundang-Undangan, Pustaka Magister, Semarang

[3] Moleong, L.J, 2004, Metodologi Penelitian, Remaja Rosda Karya, Bandung.

[4] Sudarto, 1981, Hukum dan Hukum Pidana, Alumni, Bandung.

\section{Internet}

[1] Kamus Besar Bahasa Indonesia, 2008, Pusat Bahasa Departemen Pendidikan Nasional

[2] United Nations Office on Drugs and Crime (UNODC) (5), UN Guide for AntiCorruption https://www.unodc.org/pdf/crime/corruption/UN Guide 